\title{
Responsbiliti Kurikulum Pendidikan Bahasa Arab Terhadap Wisata Syariah di Lombok-NTB
}

\author{
1Nasarudin \\ 1Universitas Muhammadiyah Mataram, Mataram, Indonesia \\ 1Doktornasar199@gmail.com
}

\begin{tabular}{|c|c|}
\hline Article Info & Abstract \\
\hline $\begin{array}{l}\text { Article History } \\
\text { Received: July 12, } 2018 \\
\text { Accepted: September 30, } \\
2018\end{array}$ & \multirow{2}{*}{$\begin{array}{l}\text { Kajian ini bertujuan untuk mengungkapkan responsibiliti kurikulum } \\
\text { pendidikan bahasa Arab dalam pengembangan wisata syariah di Lombok } \\
\text { pada dua perguruan tinggi yaitu Universitas Muhammadiyah Mataram } \\
\text { (UMMat) dan Universitas Islam Negeri (UIN) Mataram. Kurikulum } \\
\text { pendidikan bahasa Arab di Universitas Muhammadiyah Mataram dan UIN } \\
\text { Mataram merespon pengembangan pariwisata di Lombok dengan } \\
\text { memberikan peranan-peranan antara lain: menyiapkan sumber daya } \\
\text { penerjemah dan pemandu wisata, mendesain materi perkuliahan } \\
\text { berkarakter tentang pariwisata melalui mata kuliah yang bervariasi, dan } \\
\text { membangun komunikasi dengan prodi pariwasata dalam mengembangkan } \\
\text { materi bahasa Arab untuk pariwisata. }\end{array}$} \\
\hline $\begin{array}{l}\text { Keywords } \\
\text { Kurikulum; Wisata Syariah; } \\
\text { Pembelajaran Bahasa Arab }\end{array}$ & \\
\hline Support by: & \\
\hline
\end{tabular}

\section{PENDAHULUAN}

Dalam bidang pariwisata Indonesia banyak memiliki destinasi wisata sebagai tujuan utama para wisatawan baik wisatawan domestik dan wisatawan mancanegara. Bali sebagai daerah paling populer dalam industri pariwisata semenjak memiliki bandara internasional pada tahun 1969 sampai benar-benar menjadi daerah industri pariwisata pada tahun 1980 dan pada tahun 2017 Bali dinobatkan menjadi destinasi wisata terbaik dunia.

Demikian halnya dengan Lombok yang dikenal dengan daerah seribu masjid mulai menggeliat dalam pariwisata semenjak dibukanya Bandara Internasional Lombok (BIL) pada tahun 2011, terlebih semenjak tahun 2012 Indonesia mencanangkan pariwisata halal untuk mengakomodir minat wisatawan asing yang berasal dari negara-negara Islam. Pariwisata Halal menjadi branding bagi pengembangan industri pariwisata Lombok sehingga bisa menjadi tujuan wisata altrnatif.

Lombok NTB bersama Jakarta, Jawa Barat, Yogyakarta, dan Jawa Timur yang dinyatakan siap menjadi destinasi wisata syariah di antara 13 provinsi yang dipersiapkan untuk itu. Ketiga belas provinsi tersebu antara lain: Nangroe Aceh Darussalam, Sumatera Barat, Riau, Lampung, Banten, DKI Jakarta, Jawa Barat, Jawa Tengah, Yogyakarta, Jawa Timur, Sulawesi Selatan, dan Bali.

Dan pada ajang World's Halal Travel Summit yang diselenggarakan di Emirat Arab tahun 2015 Lombok terpilih sebagai World's Best Halal Honeymoon Destination (destinasi bulan madu halal terbaik dunia) dan World's Best Halal Tourism Destination (destinasi wisata halal terbaik dunia). Lombok saat ini sudah dikenal oleh dunia sebagai destinasi wisata halal terbaik dunia khususnya bagi pelancong muslim asal Timur Tengah, namun saat ini hanya memiliki 15 guide yang bisa berbahasa Arab. Karena itu bahasa Arab sangat dibutuhkan dalam mengembangkan pariwisata di Lombok, dan 
layak bahasa Arab dijadikan bahasa pariwisata setelah bahasa Inggris di daerah tersebut.

Sektor pariwisata menjadi ciri khas pulau Lombok di samping sebutannya sebagai pulau seribu masjid. Hal ini menjadi alasan kuat bagi dunia pendidikan khususnya pendidikan tinggi untuk menjadikan pariwisata (wisata syariah) menjadi penciri perguruan tinggi yang ada di Lombok, baik perguruan tinggi umum maupun perguruan tinggi Islam seperti Universitas Muhammadiyah Mataram (UMMat) dan Universitas Islam Negeri (UIN) Mataram.

Konsep wisata syariah (wisata halal) juga perlu diperkenalkan sejak dini kepada siswa di bangku sekolah secara formal dan non formal sehingga ketika mereka di perguruan tinggi dapat berkontribusi dalam pengembangan wisata syariah melalui kurikulum sejumlah program studi (prodi) yang mengembangkan kurikulumnya dengan aspek wisata sebagai pencirinya.

Kedua perguruan tinggi tersebut mengembangkan kurikulum prodinya menjadikan aspek pariwisata sebagai penciri prodi pendidikan bahasa Arab (PBA). Sebagaimana diketahui bahwa mulai tahun ajaran 2016/2017 semua prodi telah diwajibkan untuk menerapkan kurikulum pendidikan tinggi yang mengacu pada KKNI (kerangka kualifikasi nasional Indonesia), di mana semua prodi tersebut harus menentukan profil lulusannya yang terdiri dari profil utama, profil penunjang dan profil penciri.

Prodi pendidikan Bahasa Arab UMMat dan UIN Mataram merumuskan tiga profil yaitu pengajar bahasa Arab sebagai profil utama, peneliti dan penerjemah Bahasa Arab sebagai profil penunjang, dan pemandu pariwisata sebagai profil penciri program studi.

Ada beberapa kajian yang mengaitkan bahasa Arab atau Inggris dengan wisata syariah. Pertama, Dony Hendrawan mengatakan bahwa Lombok sebagai daerah wisata halal membutuhkan pemandu wisata yang profesional dalam berbahasa Arab dengan memeberikan format baru model belajar mengajar bahasa Arab yang berbasis wisata dengan menggunakan rancangan ADDIE. Kedua, Widodo dkk mengatakan bahwa bahasa Inggris memainkan peranan penting dalam pengembangan wisata pada bidang akomodasi dan transportasi karena bahasa Inggris sering dijadikan bahasa komunikasi. Demikian juga dengan bahasa Arab dijadikan bahasa komunikasi degan wisatawan dari Timur Tengah dalam bidang akomodasi dan transportasi sehingga dapat dikatakan bahwa bahasa Arab akan punya peranan penting dalam pengembangan wisata syariah. Ketiga, Jeni Khairiyah, mengatakan bahwa pariwisata memberikan peran besar dalam memperluas lapangan kerja dan mendorong kegiatan-kegiatan industri penunjang. Hal ini juga yang menjadi pertimbangan pemerhati bahasa Arab melalui lembaga pendidikan supaya outputnya dapat diterima oleh dunia kerja bukan hanya dalam dunia pendidikan tapi dalam kegiatan indutri lain, seperti jasa penterjemah, industri wisata dan pandu wisata. Keempat, Aan Jaelani mengatakan bahwa pengembangan wisata diarahkan pada pemenuhan indeks daya saing pariwisata sebagai indikator-indikator utamanya, antara lain melakukan pembenahan infrastruktur, promosi, dan penyiapan sumber daya manusia, khususnya peningkatan kapasitas pelaku usaha pariwisata. Kurikulum pendidikan bahasa Arab yang mengacu pada KKNI dan SN Dikti mengutamakan penguataan daya saing sumber daya manusia yang terwujud dalam perbaikan profil lulusan program studi untuk menjadi pelaku usaha wisata

Berdasarkan pada kajian-kajian tersebut kurikulum pendidikan bahasa Arab menempati posisi yang sangat urgen dalam mengakomodir kebutuhan dunia kerja di lingkungannya yaitu bidang pariwisata. Berkenaan dengan hal tersebut penulis hendak mengkaji respon kurikulum pendidikan bahasa Arab dalam pengembangan wisata syariah di daerah Lombok. 


\section{METODE}

Metode

\section{HASIL DAN PEMBAHASAN}

\section{Responsibiliti kurikulum pendidikan bahasa Arab dalam pengembangan pariwisata syariah di Lombok}

Bentuk sikap respon kurikulum pendidikan bahasa Arab terhadap pengembangan pariwisata syariah di Lombok antara lain:

1. Menyiapkan Sumber Daya Penerjemah dan Pemandu Wisata

Bidang wisata syariah banyak bersinggungan dengan aspek lain seperti aspek sosial, budaya dan pendidikan. Aspek-aspek tersebut banyak melibatkan sumber daya manusia selaku pelaksana dalam kelancaran wisata syariah. Salah satu wadah yang yang berperan dalam meyiapkan SDM yang profesional adalah perguruan tinggi yang memiliki prodi pendidikan bahasa Arab. Prodi PBA di UMMat dan UIN Mataram telah menyiapkan profil lulusan yang sesuai dengan karakteristik lokal yaitu berkiprah dalam dunia wisata. Sebelum dicanangkan wisata syariah di Lombok-NTB ada sebagian output prodi PBA berkecimpung dalam bidang pelayanan seperti tour and travel umrah dan haji. Dan setelah dicanangkan wisata syariah maka peranan dan partisipasi output tersebut tentu lebih besar karena makin banyak bidang lain membutuhkannya. Bidangbidang yang dimaksud adalah kuliner, pelayanan, adat istiadat, wisata alam dan lainlain.

Menurut Duran dalam Akyol dan Kilinç (2014), pariwisata memiliki bermacam dampak sosial dan budaya. Wisata halal adalah suatu produk baru dari pasar muslim dan non-muslim. Menurut Zulkifli dalam Akyol dan Kilinç (2014), pasar halal diklasifikasikan ke dalam 3 (tiga) kategori yaitu: makanan, gaya hidup (kosmetik, tekstil, dll), dan pelayanan (paket wisata, keuangan, transportasi). Menurut Duman dalam Akyol dan Kilinç, Islamic tourism didefinisikan sebagai:"the activities of Muslims travelling to and staying in places outside their usual environment for not more than one consecutive year for participation of those activities that originate from Islamic motivations which are not related to the exercise of an activity remunerated from within the place visited" (Kilinç, 2014 ).

Dalam bidang kuliner para wisatawan butuh referensi yang memadai untuk mengetahui jenis makanan yang menjadi kekhasan lokal di pulau Lombok yang dijamin kehalalannya. Referensi kuliner tersebut disiapkan melalui berbagai macam penelitian terutama pengembangan sehingga dapat menghasilkan produk berupa daftar menu makanan khas Lombok yang menggunakan bahasa Arab.

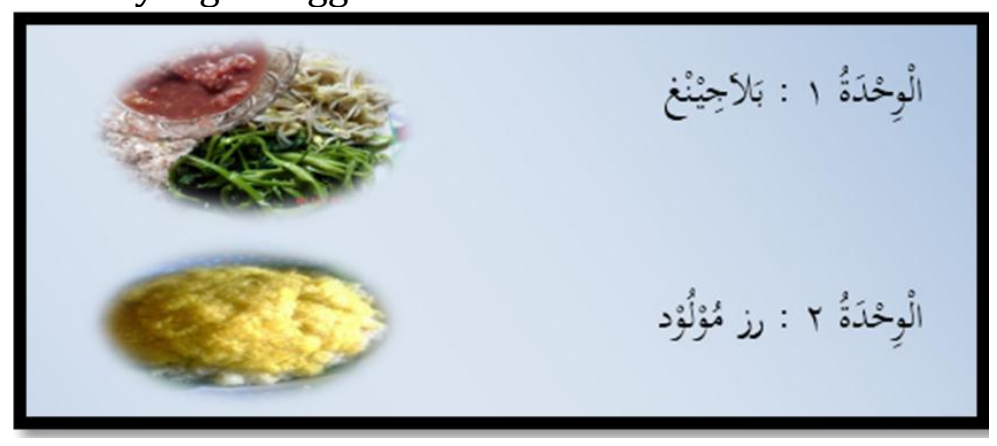

Gambar 1: Makanan khas Lombok.

Dari gambar 1 tersebut disajikan contoh makanan khas daerah pulau Lombok yaitu pelecing dan nasi rasul. Kedua makanan tersebut menjadi khas makanan Lombok. Pelecing sebagai kategori sayur mayor yang disajikan bersama ketupat ataupun nasi putih dengan citra rasa pedas yang difilosofikan dengan nama Lombok yang 
diasumsikan dengan cabe meskipun kata lombok berasal dari bahasa Sasak berarti lurus (tidak bengkok).

Dalam bidang adat istiadat Lombok mempunyai adat tersendiri yang perlu diketahui oleh para wisatawan. Berbagai adat tersebut perlu mempunyai deskripsi bahasa Arab yang membutuhkan keterlibatan pemerhati bahasa Arab yang berasal dari lulusan bahasa Arab.

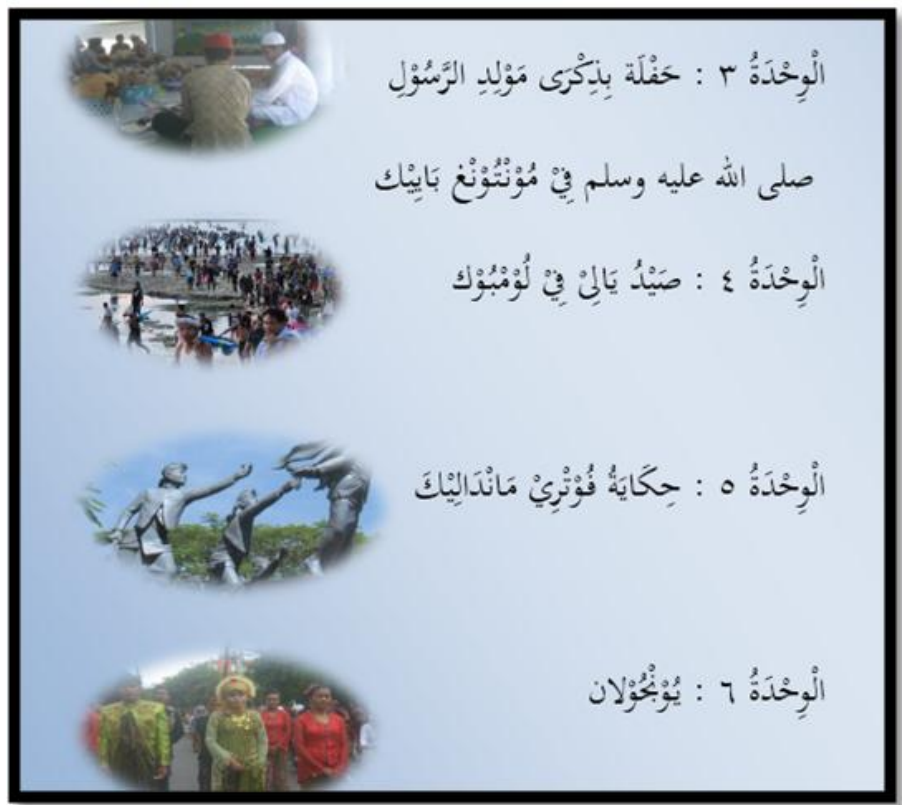

Gambar 2: Adat Istiadat Penduduk Lombok

Berdasarkan gambar 2 tersebut ada empat tradisi dalam masyarakat Sasak yaitu mulud, bau nyale, mandalika, dan nyongkolan. Perayaan mulud sebagai kelahiran Rasulullah yang dirayakan setiap bulan Rabiul Awal dengan menyajikan makanan khas yaitu nasik rasul. Acara bau nyale (sejenis cacing laut) pada saat musim penghujan di laut lombok bagian selatan, ini berkaitan dengan mitos putri Mandalika. Cerita Putri Mandalika merupakan cerita rakyat di mana seorang putri raja menjadi rebutan para putra raja-raja yang lebih memilih jadi nyale dari pada memilih salah satu putra raja tersebut. Dan bentuk adat yang lain yaitu nyongkolan atau nyondol, acara ini berkaitan dengan adat pernikahan Lombok di mana setelah acara pesta pernikahan kedua mempelai bersama keluarga berkunjung ke rumah orang tua mempelai perempuan yang diiringi dengan pendamping yang berapakaian adat dan biasanya disertai musik bernama gendang blek dan kecimol.

Untuk mengemas semua hal-hal yang menjadi ciri khas daerah Lombok tersebut dibutuhkan praktisi bahasa Arab melalui penelitian, penerjemah dan pemandu wisata sehingga para wisatawan merasa dimanjakan dalam menyongsong Lombok sebagai destinasi wisata syariah dunia. Dalam mengakomodir kelengkapan SDM tersebut kurikulum mempunyai peranan penting dalam mempersiapkan SDM melalui penentuan profil lulusan sesuai dengan dunia kerja dan pangsa pasar di daerah tempat keberadaannya.

Suatu studi di Malaysia menyebutkan bahwa pramuwisata yang bisa berbahasa Arab sangat membantu para wisatawan ketika berinteraksi dengan petugas hotel/warga lokal. Bukan hanya itu, kebutuhan akan bahasa Arab juga dirasakan oleh pihak hotel. Petugas hotel yang dapat melayani tamu dengan bahasa Arab diyakini dapat meningkatkan citra hotel itu di mata para wisatawan.

Kurikulum pendidikan bahasa Arab harus lebih profesional mempersiapkan SDM wisata syariah dari pada kurikulum pariwisata yang sama-sama mengemban misi 
mengembangkan wisata syariah. Prodi pariwisata juga mempersiapkan pemandu wisata yang mampu berbahasa Arab. Dalam sebuah penelitian terhadap mahasiswa STIE Pariwisata YAPARI yang belajar bahasa Arab dilaporkan bahwa mahasiswa mengharapkan agar dosen mengajar bahasa itu melalui games dan menggunakan video bagaimana orang Arab berkomunikasi. Ini dimaksudkan agar mereka bisa berbicara dengan wisatawan Arab jika ia menjadi tour guide. Hal ini dikuatkan oleh pemaparan bahwa metode mengajar yang efektif melingkupi bermacam potensi/kemampuan, minat, karakteristik, pengalaman, kebutuhan, kebiasaaan, dan gaya belajar peserta didik. kondisi, potensi, tingkat kemampuan, minat, motivasi, masalah, gaya, dan kecepatan belajar peserta didik.

2. Mendesain materi perkuliahan berkarakter tentang pariwisata melalui mata kuliah yang bervariasi

Untuk mencapai profil lulusan prodi yang sudah ditetapkan dalam rancangan kurikulum diperlukan mata kuliah yang menunjang secara signifikan. Mata kuliah yang dikembangkan di kedua prodi pendidikan bahasa Arab UMMat dan UIN Mataram adalah Bahasa Arab untuk pariwisata. Dengan mata kuliah ini mahasiswa mampu menguasai kosakata Arab yang berkaitan dengan pariwisata dan bidang-bidang lain yang berkaitan dengan wisata syariah.

Mata kuliah lain yang dikembangkan untuk menopang pariwisata adalah tarjemah fauriyah bertujuan untuk membekali mahasiswa untuk bisa menterjemahkan secara langsung pesan-pesan lisan yang disampaikan wisatawan berbahasa Arab.

Dibandingkan dengan pengajaran bahasa Arab yang bersifat umum, pengajaran bahasa Arab untuk pariwisata memiliki tujuan yang spesifik, yaitu untuk meningkatkan kompetensi SDM pariwisata dalam memberikan pelayanan kepada para wisatawan Arab, baik yang datang ke Indonesia maupun di negara mereka sendiri. Tujuannya pun bersifat spesifik, (li agrāọ khāșṣah), berbeda dengan tujuan pembelajaran bahasa Arab pada umumnya. Perbedaan tujuan pada gilirannya akan berpengaruh pada apa yang mesti dipelajari dan bagaimana mengajarkannya (pendekatan dan metode).

Selain itu juga ada mata kuliah bahasa Arab ammiyah yaitu bahasa Arab umum yang biasa digunakan berkomonikasi antar orang Arab di daerahnya masing-masing. Dalam kesehariannya misalnya Arab Saudi tidak menggunakan bahasa resmi Arab yang disebut dengan bahasa Arab fusha melainkan bahsa Arab ammiyah yang agak berbeda dengan bahasa Arab fusha. Bahasa Arab ammiyah banyak dipersiapkan untuk tenaga kerja asing yang akan bekerja di negara Arab seperti tenaga kerja Indonesia yang bekerja di Arab Saudi.

Dialek 'ammiyyah ini memiliki banyak varian dengan luas wilayah penggunaan yang bervariasi pula. Luasnya wilayah penggunaan bahasa Arab, dari benua Asia sampai Afrika, yang melingkupi dua puluh dua negara, dengan penutur lebih dari dua ratus juta jiwa, telah menyebabkan varian-varian dari ragam itu berbeda satu sama lain meskipun masih berada dalam satu bahasa yang sama. Dari ciri-ciri linguistik serta wilayah penggunaannya, varian-varian itu dapat kita kelompokkan ke dalam lima kelompok besar. Masing-masing kelompok dapat mencakup satu wilayah penggunaan atau lebih. Kelompok ragam itu antara lain: a) Ragam Irak (digunakan di Irak dan sebagian kawasan perbatasannya). b) Ragam Teluk (digunakan di negara-negara Teluk, seperti Arab Saudi, Kuwait, Qatar, Bahrain dan sekitarnya). c) Ragam Syam yang digunakan di negara-negara seperti Suriah dan Lebanon. d) Ragam Mesir digunakan di Mesir, Libya dan Sudan. e) Ragam Maroko dan sekitarnya digunakan di negara-negara di Afrika Utara sebelah barat Libya, seperti Maroko, Tunisia dan Aljazair.

Contoh ragam bahasa Arab 'ammiyah dalam mengungkapkan "Saya mau pergi sekarang”, ragam Irak "Areed aruuh hessa”, ragam Syam "Biddi ruuh haellaee”, ragam 
Teluk "Abghaa aruuH daHHeen", ragam Mesir "aawiz aruuH dilwa'ti” dan ragam Mesir "Bgheet nimshi daaba". Keberagaman dialek inilah yang menyebabkan keharusan dalam menentukan prioritas dalam pengajaran dialek-dialek `ammiyyah tersebut. Melihat dari data di atas, kembali ditekankan bahwa dialek `ammiyyah yang paling diperlukan untuk saat ini adalah dialek Teluk dan Mesir. Hal ini mungkin saja berubah seiring tren dan target yang juga mengalami perubahan dari waktu ke waktu.

3. Membangun komunikasi dengan prodi pariwisata dalam mengembangkan materi bahasa Arab untuk pariwisata

Kurikulum pendidikan bahasa Arab merespon perkembangan wisata syariah dengan melakukan komunikasi dengan jurusan pariwisata untuk lebih berperan aktif dalam mengembangkan wisata syariah tersebut dengan bekerja sama dan melibatkan pihak lain seperti perguruan tinggi pariwisata, dinas pariwisata, lembaga pelatihan bahasa, lembaga tour and travel, mayarakat di sekitar destinasi wisata, dan lain-lain.

Berkomunikasi dengan perguruan tinggi yang mempunyai program studi pariwisata seperti Sekolah Tinggi Pariwisata Mataram yang memiliki tiga program studi yaitu prodi S1 pariwisata, prodi S1 perhotelan dan prodi S1 perjalanan wisata, dan Universitas Mataram yang memiliki jurusan D3 pariwisata, Politeknik Pariwisata Lombok dan UIN Mataram yang memiliki jurusan S1 pariwisata syariah sejak tahun 2016, dalam rangka pengembangan meteri yang berkaitan dengan wisata syariah dan bahasa Arab. Bentuk komunikasi antar perguruan tinggi tersebut dapat bewujud kegiatan workshop dalam pengembangan materi pelajaran bahasa Arab..

\section{SIMPULAN}

Dalam kajian ini dapat disimpulkan bahwa kurikulum pendidikan bahasa Arab di Universitas Muhammadiyah Mataram dan UIN Mataram merespon pengembangan pariwisata di Lombok dengan memberikan peranan-peranan antara lain: menyiapkan sumber daya penerjemah dan pemandu wisata, mendesain materi perkuliahan berkarakter tentang pariwisata melalui mata kuliah yang bervariasi, dan membangun komunikasi dengan prodi pariwisata dalam mengembangkan materi bahasa Arab untuk pariwisata.

\section{DAFTAR PUSTAKA}

[1] Aji Sudarsono. (2016).Jaringan Syaraf Tiruan Untuk Memprediksi Laju Pertumbuhan Penduduk Menggunakan Metode Bacpropagation (Studi Kasus Di Kota Bengkulu).Jurnal Media Infotama,12(1), 61-69

[2] Abdillah, M. Zaki. (2018). "Internalisasi Ekonomi Islam dalam Wisata Halal" Lombok Post.

[3] Andriani, Dini. dkk. (2015). "Kajian Pengembangan Wisata Syariah”, Laporan Akhir, Asisten Deputi Penelitian Dan Pengembangan Kebijakan Kepariwisataan Deputi Bidang Pengembangan Kelembagaan Kepariwisataan Kementerian Pariwisata.

[4] Ernawati, Euis. (2018 ). "Perencanaan Pembelajaran Bahasa Arab di Perguruan Tinggi Pariwisata", Arabiyat: Jurnal Pendidikan Bahasa Arab dan Kebahasaaraban Vol. 5 No. 1, Juni 2018

[5] Firdausi, Izza et al. (2017). "Lombok: Halal Tourism as a New Indonesia Tourism Strategy", 4th International Conference on Humanities, Social Sciences and Education (ICHSSE-17) March 13-14, Dubai (UAE)

[6] Hamzah \& Yudiana. (2015). dalam Dini Andriani, dkk., Kajian Pengembangan, 12

[7] Hendrawan, Dony. (2016). "New Perspective on Arabic Teaching and Learning in Lombok as the World Halal Tourism Destination", Report of Research.

[8] http://forlap.ristekdikti.go.id 
[9] http://liputan6.com

[10] http://travel.kompas.com

[11] Jaelani, Aan. (2017). "Halal tourism industry in Indonesia: Potential and Prospects", MPRA Munich Personal RePEc Archive, Faculty of Shari'ah and Islamic Economic, IAIN Syekh Nurjati Cirebon.

[12] Kaelany, HD. (2004). Pariwisata Dalam Pandangan Islam. (Jakarta : Misaka Galiza).

[13] Khairiyah, Jeni. (2009). "Pengaruh Perkembangan Pariwisata terhadap Budaya dan Bahasa”, Kertas Karya, Fakultas Sastra, Universitas Negeri Sumatera Utara.

[14] Misran. (2013). "Dialek 'Ammiyyah Dalam Pengajaran Bahasa Arab Untuk Pariwisata di Indonesia" Adabiyyāt, Vol. XII, No. 2, Desember 2013

[15] Nasarudin. (2014). "Prospek Bahasa Arab dalam Pengembangan Pariwisata di Lombok NTB”, Lugatuna Vol. 4, No. 2, Universitas Muhammadiyah Mataram.

[16] Nasarudin. (2018). "Tatbiq Manhaj Taklimil Lugatil Arabiyah ala Asasit Tahsilid Dirasiy li Tarqiyati Jaudatit Taklim, Desertasi, Pendidikan Bahasa Arab, UIN Maulana Malik Ibrahim Malang.

[17] Peraturan Menteri Pariwisata dan Ekonomi Kreatif Nomor 2 tahun 2014 tentang Pedoman Penyelenggaraan Usaha Hotel Syariah, point (c).

[18] Perda NTB Nomor 2 Tahun 2016 tentang Pariwisata Halal, Bab (1) Pasal (1)/16.

[19] Rauhillah, Percakapan Bahasa Arab Bertema Budaya Lokal

[20] Sofyan, Riyanto. (2015). Prospek Bisnis Pariwisata Syariah, (Jakarta: Republika).

[21] Widodo, dkk. (1996). "Peranan Bahasa Inggris dalam Mengembangkan Wisata di Semarang”, Laporan Peneletian, Fakultas Sastra, Universitas Negeri Ponorogo Semarang. 